\title{
Makan Besaprah: Pesan Dakwah dalam Bingkai Tradisi pada Masyarakat Melayu Sambas
}

\author{
Mualimin \\ Institut Agama Islam Negeri Palangkaraya, Indonesia \\ Jln. G. Obos Komplek Islamic Centre Palangkaraya, Kalimantan Tengah \\ mualimin@iain-palangkaraya.ac.id
}

\begin{abstract}
This study aims to analyze the message of da'wah in the tradition of besaprah (eating together). This research is a qualitative interpretive paradigm. Data were collected in three ways, through observation, interviews, and document studies. While the method used to analyze data is the semiotics method. Based on the analysis that has been done, can be concluded that the teachings of Islam are conveyed through cultural symbols that are packaged properly in the tradition of besaprah. The message of da'wah in the tradition of besaprah is conveyed through cultural symbols. In general the message of $d a^{\prime}$ wah can be divided into three aspects of Islamic teachings. First, the message of faith is related to monotheism and the pillars of faith. Second, the message of sharia is related to observance of implementing Islamic teachings in daily life. Third, the moral message related to friendship, mutual help, glorify humans, and equality between human beings.
\end{abstract}

Keywords : Da'wah Message, Makan Besaprah, Sambas Malay 


\section{A. Pendahuluan}

Sejarah perjalanan kesultanan Sambas mencatatkan bahwa sebelum masuknya Islam, agama Hindu dan Budha menjadi agama yang banyak dianut oleh masyarakat Sambas. Ketika Islam masuk di Sambas, gerakan dakwah Islam dilakukan dengan internalisasi ajaran Islam dalam setiap nafas kehidupan masyarakat. Upaya tersebut bertujuan untuk memasyarakatkan ajaran Islam, sehingga bagi yang belum memeluk Islam diharapkan tertarik untuk memeluk Islam. Sedangkan bagi masyarakat Sambas yang telah memeluk Islam, internalisasi ajaran Islam bertujuan untuk semakin memperkuat keimanannya. ${ }^{1}$ Tujuan ini sangat realistis karena dengan internalisasi tersebut Islam akan menjadi bagian penting bagi orang Sambas. Bahkan sangat memungkinkan dengan adanya internalisasi tersebut, setiap budaya yang bernafaskan Islam menjadi sesuatu yang prestisius bagi rakyat ketika itu.

Internalisasi ajaran Islam dilakukan dalam berbagai bidang kehidupan. Internalisasi ajaran Islam bahkan hingga dalam sistem sosial yang terkecil sekalipun seperti tatacara makan dan minum yang disebut dengan makan besaprah. Bagi Melayu Sambas tradisi makan besaprah telah menyatu dalam kehidupan sosialnya. Hal ini terlihat dari realitas bahwa tradisi ini tidak hanya dilakukan dalam acara adat saja, tetapi juga dilakukan dalam kehidupan sehari-hari.

Internalisasi ajaran Islam dalam tradisi makan besaprah pada dasarnya merupakan bagian dari dakwah kultural. Pada tataran ini Astori dan Librianti mengemukakan bahwa dakwah kultural merupakan bagian dari upaya dakwah melalui pendekatan budaya yang hidup dan berkembang di masyarakat. Pada tataran ini kebiasaan dan adat istiadat suatu masyarakat menjadi pertimbangan dalam mengemas pesan dakwah sehingga lebih mudah untuk menarik minat sasaran dakwah. ${ }^{2}$ Selain itu dakwah kultural juga merupakan bagian dari bentuk dakwah melalui pendekatan damai. Oleh karena itu senada dengan pendapat tersebut, beberapa kajian menunjukkan pentingnya pemilihan metode dan teknik berdakwah agar dapat menarik minat mad'u serta memberikan dampak dalam mewujudkan ajaran yang

1 Pabali Musa, "Tahapan-Tahapan Sejarah Sambas" (Makalah, Dies Natalis STAI Sambas tahun 2010, Sambas, 2010), 2.

2 Asep Kamil Astori dan Eka Octalia Indah Librianti, “Dakwah Kultural: Relasi Islam Dan Budaya Lokal," Ath Thariq Jurnal Dakwah Dan Komunikasi 3, no. 2 (26 Februari 2020): 177, https://doi.org/10.32332/ath_thariq.v3i2.1548. 
rahmatan lil 'alamin. ${ }^{3}$

Ajaran Islam yang menjadi substansi pesan dakwah dalam tradisi makan besaprah dikemas dengan begitu baik. Pesan-pesan dakwah tersebut direpresentasikan terutama dalam tatacara pelaksanaan tradisi ini. Kerapian dalam mengemas tradisi ini membuat masyarakat tertarik untuk mempertahankannya dalam kehidupan. Faktor inilah yang kemudian membuat tradisi ini mampu bertahan hingga saat ini bahkan semakin menguat khususnya di kalangan masyarakat Melayu Sambas. Eksistensi ini terlihat dari hingga saat ini setiap tradisi adat masyarakat tidak sempurna jika cara makannya tidak dengan besaprah.

Pesan-pesan yang terkandung dalam tradisi makan besaprah menarik untuk dibedah dan ditafsirkan dalam sebuah penelitian. Secara umum, penelitian ini terfokus pada pesan-pesan dakwah dalam tradisi makan besaprah terutama terkait pesan akidah, syariat, dan akhlak. Oleh karena itu, penelitian ini menggunakan teori pesan dakwah sebagai pisau analisis terutama dalam pemetaan pesan dakwah tradisi makan besaprah.

\section{B. Metode Penelitian}

Penelitian ini merupakan penelitian kualitatif dengan menggunakan metode semiotika. Pengumpulan data dalam penelitian ini dilakukan pada bulan Maret hingga Mei 2019. Pengumpulan data dalam penelitian ini dilakukan melalui tiga cara, yaitu melalui observasi. Observasi dilakukan sebanyak 3 kali dengan terfokus kepada pelaksanaan makan besaprah dari tahap persiapan hingga akhir. Kedua, data dikumpulkan melalui wawancara mendalam kepada informan. Untuk menjaga hak privasi, identitas informan dalam penelitian ini dirahasiakan. Ada tiga aspek utama yang akan digali melalui wawancara yaitu tahapan pelaksanaan makan besaprah dari awal hingga akhir, simbol budaya dalam makan besaprah, dan pesan dakwah dalam makan besaprah. Ketiga, pengumpulan data melalui studi dokumenter. Data yang diperoleh melalui studi dokumenter ini berupa foto, naskah

3 Herles Anwar dan Mualimin, “Dakwah Melalui Pembinaan Keagamaan Terhadap Masyarakat Muslim Pedalaman Oleh Penyuluh Agama Islam Non PNS Kecamatan Tebas, Sambas," Jurnal Bimbingan Penyuluhan Islam 1, no. 01 (30 Juni 2019): 24; Ferdian Achsani dan Siti Aminah Nur Laila, "Pesan Dakwah Dalam Lirik Lagu Menyambut Lebaran Karya Pendhoza," NALAR: Jurnal Peradaban Dan Pemikiran Islam 3, no. 2 (2019): 123, https:/ / doi.org/10.23971/njppi.v3i2.1435. 
dan literatur yang relevan dengan tradisi makan besaprah.

\section{Pesan Dakwah}

Pesan merupakan sesuatu yang bersifat abstrak. Agar menjadi sesuatu yang konkret, manusia kemudian menciptakan lambang dalam menciptakan pesan tersebut. Lambang dari suatu pesan dapat berupa simbol tulisan, suara, raut wajah maupun gerak tubuh. Oleh karena itu wajar jika pesan seringkali didefinisikan sebagai seperangkat lambang yang memiliki makna dalam aktivitas komunikasi manusia. Sejalan dengan definisi tersebut, Hafied Cangara dalam Aziz, memandang bahwa pesan adalah sesuatu yang disampaikan pengirim kepada penerima. ${ }^{4}$ Menurut Asmuni Sukir, Pesan merupakan gagasan dan pernyataan sikap yang disampaikan kepada orang lain. ${ }^{5}$

Pada dasarnya, pesan merupakan intisari dalam sebuah komunikasi. Dalam konteks ini, ketersampaian pesan menjadi syarat yang sangat menentukan efektivitas setiap komunikasi yang terjadi antara manusia. Oleh karena itu cara menyampaikan suatu pesan menjadi sangat krusial agar pesan yang ingin disampaikan diterima dan difahami dengan baik. ${ }^{6}$

Pesan secara umum dapat dikategorikan verbal dan non verbal. Bahasa verbal adalah adalah alat untuk menyampaikan gagasan, perasaan dan maksud manusia dengan menggunakan kata-kata. ${ }^{7}$ Definisi yang disampaikan Deddy Mulyana pada dasarnya ingin menunjukkan bahwa bentuk dari pesan verbal adalah kata-kata. Pesan non verbal dapat diartikan sebagai setiap isyarat atau bahasa yang bukan dalam bentuk kata-kata. Definisi ini berdasarkan pendapat beberapa ahli. Samovar dan Porter memandang pesan non verbal mencakup semua rangsangan non verbal dalam satu setting komunikasi dan memiliki nilai potensial bagi pengirim atau penerima pesan. ${ }^{8}$ Definisi ini menunjukkan bahwa perilaku manusia baik yang disengaja maupun tidak merupakan bagian dari pesan non verbal.

4 Moh Ali Aziz, Ilmu Dakwah (Jakarta: Kencana, 2009), 112.

${ }^{5}$ Asmuni Sukir, Dasar-Dasar Strategi Dakwah (Surabaya: Al-Ikhlas, 1983), 60.

6 Mondry, Pemahaman Teori dan Praktik Jurnalistik (Bogor: Ghalia Indonesia, 2008), 8 .

7 Deddy Mulyana, Ilmu Komunikasi: Suatu Pengantar (Bandung: Remaja Rosdakarya, 2007), 261.

8 Mulyana, 343. 
Pesan non verbal dapat diklasifikasikan menjadi beberapa macam. Menurut Samovar dan Porter bentuk pesan non verbal terbagi menjadi dua. Pertama, segala bentuk perilaku manusia seperti cara perpenampilan, gestur tubuh, mimik wajah, tatapan mata, sentuhan, dan aroma. Kedua, ruang, waktu, dan bunyi.

Pesan merupakan komponen penting dalam aktivitas dakwah. Menurut Sukayat, ajaran Islam yang merupakan intisari dari pesan dakwah yang harus disampaikan. Isi pesan tersebut yaitu keseluruhan ajaran Islam yang ada dalam Al-Qur'an dan hadis. ${ }^{9}$ Menurut Aziz, pesan dakwah adalah setiap pesan komunikasi yang mengandung muatan nilai-nilai keilahian, ideologi, dan kemaslahatan baik secara tersirat maupun tersurat. ${ }^{10}$

Kemasan dan cara penyampaian pesan menurut Widodo menjadi sangat menentukan bagi keberhasilan dakwah. ${ }^{11}$ Menurut Abdul Basit, ada tiga aspek yang mesti diperhatikan terkait dengan pesan dakwah. Pertama, pesan dakwah menggambarkan sejumlah kata atau imajinasi tentang dakwah yang diekspresikan dalam bahasa. Pada tataran ini terdapat dua aspek yaitu isi pesan dan lambang pesan. Kedua, pesan dakwah terkait dengan makna yang dipersepsi atau diterima seseorang. Makna merupakan hasil yang ditimbulkan dari kerja sama antara sumber dengan penerima pesan. Pemahaman terhadap pemaknaan pesan oleh penerima pesan akan memaksimalkan pengelolaan pesan baik verbal maupun non verbal. Ketiga, pemaknaan dan pemahaman pesan oleh sasaran dakwah. Aspek ketiga ini menunjukkan bahwa sangat dimungkinkan adanya perbedaan pemaknaan dan pemahaman pesan dakwah antara setiap orang. ${ }^{12}$

Pada dasarnya, sumber dari pesan dakwah adalah Al-Qur'an, Hadis, serta sistem sosial dalam kehidupan manusia. Pada tataran ini pesan dakwah menurut Endang Saifuddin Anshari terbagi menjadi tiga ${ }^{13}$, yaitu sebagai berikut:

1. Pesan Akidah

9 Tata Sukayat, Ilmu Dakwah Perspektif Filsafat Mabadi 'Asyarah (Bandung: Simbiosa Rekatama Media, 2015), 25-26.

10 Aziz, Ilmu Dakwah, 144.

11 Anton Widodo, "Dakwah Di Era Revolusi Industri 4.0," Khabar 1, no. 1 (31 Desember 2019): 50, https://doi.org/10.37092/khabar.v1i1.120.

12 Abdul Basit, Filsafat Dakwah (Jakarta: Raja Grafindo Persada, 2013), 140-41.

13 Endang Saifudin Anshari, Wawasan Islam: Pokok-Pokok Pikiran tentang Paradigma dan Sistem Islam (Jakarta: Gema Insani, 2004), 44-46. 
Akidah merupakan bagian terpenting dalam ajaran Islam. hal ini karena akidah menjadi fondasi utama dari seluruh ajaran Islam. Pesan akidah dalam dakwah pada dasarnya bermuara pada rukun iman. Penekanan pesan akidah dalam proses dakwah adalah untuk tetap memegang teguh keyakinan dalam rukun iman dan jangan sampai meragukannya.

2. Pesan Syariat

Syariat secara kebahasaan dapat diartikan sebagai jalan menuju sumber mata air. Berangkat dari arti tersebut, syariat dapat diartikan sebagai sistem atau norma ilahiah yang harus dilakukan agar dapat menjembatani setiap muslim untuk mendekatkan diri kepada Allah Swt. ${ }^{14}$ Pada tataran ini syariat Islam adalah suatu sistem norma Ilahi yang mengatur kehidupan manusia dengan Tuhan dan sesama makhluk.

Pesan syariat menurut Endang Saifuddin Anshari berhubungan erat dengan dua bidang. Pertama bidang ibadah yang berhubungan erat dengan tata aturan hubungan langsung antara umat Islam dengan Allah Swt. Kedua, bidang muamalah adalah aturan terkait hubungan manusia dengan sesama ciptaan Allah Swt. Pada tataran ini secara umum pesan dakwah adalah terkait aturan dalam aspek kehidupan sosial manusia seperti kepemimpinan, politik, jual beli, keluarga, budaya, dan aspek kehidupan sosial lainnya. Oleh karena itu pesan dakwah muamalah juga bersumber dari norma dan nilai yang dianut masyarakat.

3. Pesan Akhlak

Akhlak berasal kata khuluq yang dapat diartikan dengan perilaku, kebiasaan, dan tabiat. Derivasi kata ini memiliki kesamaan dengan khalqun yang artinya kejadian. Menurut Munir dan Ilaihi, kata khalqun kemudian bermuara dan erat hubungannya dengan kata makhluk yang artinya ciptaan. ${ }^{15}$ Dengan demikian didefinisikan sebagai perilaku, kebiasaan dan tabiat seseorang. Pada tataran ini akhlak dapat bersifat positif maupun negatif. Akhlak yang positif misalnya amanah, sabar, dan jujur.

\footnotetext{
14 Yantos Yantos, "Analisis Pesan-Pesan Dakwah Dalam Syair Lagu Opick," Jurnal Dakwah Risalah 24, no. 2 (1 November 2013): 22, https://doi.org/10.24014/jdr.v24i2.20.

15 Muhamad Munir dan Wahyu Ilaihi, Manajemen Dakwah (Jakarta: Kencana, 2015), 28.
} 
Pesan akhlak berorientasi untuk membangun tatanan kehidupan sosial yang baik. Oleh karena itu pesan akhlak dalam aktivitas dakwah mestinya tidak hanya pada tataran konseptual, tetapi juga terkait dengan implementasi akhlak tersebut dalam kehidupan sehari-hari. Pada tataran ini pada dasarnya akhlak terkait dengan kualitas perilaku manusia yang merepresentasikan kondisi kejiwaannya. Akhlak yang baik merupakan kondisi kejiwaan seseorang yang bersih dari sifat tercela. Kemuliaan akhlak tersebut merupakan refleksi dari keimanan kepada Allah SWT.

\section{Hasil Dan Pembahasan}

\section{Gambaran Lokasi Penelitian}

Kabupaten Sambas terletak di bagian paling utara Provinsi Kalimantan Barat. Secara geografis kabupaten Sambas terletak diantara 1'23" Lintang utara dan 108'39" Bujur Timur. ${ }^{16}$ Mayoritas penduduk Kabupaten Sambas menganut agama Islam. Ditahun 2015 pemeluk agama Islam sebanyak 548,306 orang atau sekitar 87,39 dari total penduduk kabupaten Sambas. Sedangkan penduduk yang beragama Kristen sebanyak 11,311 orang atau sekitar 1,8 persen dari total penduduk. Penganut Khatolik sebanyak 17, 527 orang atau sekitar 2,79 persen dari total penduduk. Pemeluk Hindu sebanyak 273 orang atau sekitar 0,04 persen dari total penduduk. Pemeluk Budha sebanyak 47,223 orang atau sekitar 7,53 persen dari total penduduk.

\section{Esensi Tradisi Makan Besaprah}

Makan besaprah pada dasarnya merupakan tradisi terkait tatacara makan dalam masyarakat Melayu Sambas. Asal usul kata makan besaprah menurut Arpan berasal dari kata saprah atau nyaprah yang dalam bahasa Melayu Sambas dapat diartikan duduk melingkar di atas lantai, berkumpul, berkelompok, bulat. Secara terminologi, istilah makan besaprah dalam masyarakat Melayu Sambas digunakan untuk menunjukkan budaya makan bersama dengan duduk bersila di atas lantai dan secara berkelompok dengan membentuk lingkaran. Dalam satu saprahan biasanya terdiri

16 Pemerintah Daerah Kabupaten Sambas, "Kondisi Umum Kabupaten Sambas," diakses $12 \quad$ April 2020, daerah/pemerintahan/kondisi-umum.html. 
dari 5-6 orang. ${ }^{17}$ Namun pada acara atau perayaan tertentu, dapat ditemukan juga saprahan yang terdiri dari 4 orang seperti yang ditemukan dalam acara naikkan tullang bumbungan.

Tradisi makan besaprah sudah mengakar dalam kehidupan masyarakat Melayu Sambas. Pada tataran ini kebiasaan makan keluarga dengan besaprah selalu dipraktekkan dalam kehidupan sehari-hari. Bahkan tamu yang datang selalu akan disuguhkan makan dengan cara besaprah. Selain itu tradisi makan besaprah dapat dengan sangat mudah ditemukan dalam setiap perayaan maupun acara yang dilakukan dalam Melayu Sambas. Bahkan acara dan perayaan seperti adat istiadat pernikahan, tepung tawar, sya'banan dan miare tidak akan sempurna jika tidak dengan besaprah. Begitu pentingnya tradisi makan besaprah sehingga dijadikan patokan untuk mengetahui meriah atau tidaknya pelaksanaan suatu acara atau perayaan.

Tradisi makan besaprah melibatkan banyak orang dalam pelaksanaannya. Keterlibatan banyak orang tersebut terutama untuk menyuguhkan saprahan pada acara dan perayaan-perayaan yang dilaksanakan masyarakat Melayu di Sambas. Pada konteks ini kerjasama dan gotong royong merupakan faktor penentu keberhasilan pelaksanaan tradisi makan besaprah tersebut.

\section{Pesan Dakwah dalam Tradisi Makan Besaprah}

Islam sangat erat dalam kehidupan sosial budaya Melayu Sambas. Hubungan yang begitu eratnya antara Islam dengan Melayu Sambas sehingga Melayu dan Islam cenderung dipandang saling merepresentasikan antara satu sama lain. Pada tataran ini Melayu tidak hanya dianggap sebagai identitas kesukuan, tetapi juga merepresentasikan agama seseorang yaitu Islam. Oleh karena itu wajar jika dalam kehidupan masyarakat Melayu Sambas, seseorang yang melakukan konversi agama dari non Muslim menjadi Muslim cenderung lebih sering disebut dengan Masuk Melayu dibandingkan dengan sebutan menjadi muallaf. Begitu juga sebaliknya, seorang muslim yang melakukan konversi agama menjadi non Muslim seringkali akan disebut masuk Dayak atau masuk Cina.

17 S Arpan, Saprahan: Adat Budaya Melayu Sambas (Tebas: Arjuna Offset, 2009), 2; Fathan Mun'in, “Eksistensi Tradisi Pembacaan Assalai/Asy'rakal dan Makan Besaprah pada Pesta Pernikahan Masyarakat Melayu Kabupaten Sambas Perspektif Ekonomi Islam," Khatulistiwa: Journal Of Islamic Studies 1, no. 2 (2017): 20. 
Realitas di atas menunjukkan bahwa Islam memiliki pengaruh penting dalam kehidupan Melayu Sambas. Pengaruh tersebut diantaranya sebagai penopang eksistensi suatu budaya dalam masyarakat Melayu Sambas termasuk tradisi makan besaprah. Oleh karena itu wajar jika tradisi makan besaprah yang merupakan produk budaya tetap dipertahankan oleh Melayu Sambas karena tidak bertentangan dengan ajaran Islam.

Realitas bahwa agama berkontribusi sebagai penopang keberadaan suatu budaya dalam masyarakat pada dasarnya sangat wajar. Terkait dengan itu, Setiyawan memandang bahwa agama menjadi sumber etika dan moral yang absolut di satu sisi dan menjelma sebagai sistem kebudayaan di sisi yang lain. Penjelmaan agama sebagai sistem kebudayaan terjadi apabila manusia merespon wahyu dan merefleksikannya dalam kehidupan sehingga bertransformasi menjadi suatu gejala kebudayaan. Pada konteks inilah kemudian agama menjelma sebagai penopang utama dan kekuatan mobilisasi budaya dalam suatu masyarakat. ${ }^{18}$

Adanya kontribusi Islam dalam tradisi makan besaprah, secara tidak langsung menyiratkan bahwa pesan di dalamnya merupakan penjelmaan dari ajaran Islam dalam simbol-simbol budaya. Makna simbol tersebut merupakan pesan dakwah untuk setiap individu yang terlibat dalam tradisi makan besaprah. Pandangan ini sebagaimana yang dikemukakan oleh Anshari bahwa pesan dakwah merupakan bagian dari ajaran Islam. ${ }^{19}$ Merujuk pendapat tersebut dapat disimpulkan bahwa pesan simbolik dalam tradisi makan besaprah merupakan pesan dakwah.

Pesan dakwah terkait dengan substansi materi yang disampaikan dalam dakwah. Penyampaiannya dapat dilakukan melalui berbagai cara diantaranya sebagaimana yang dikemukakan oleh Mualimin yaitu melalui simbolisasi pesan dakwah dalam budaya. ${ }^{20}$ Menurut Sukayat pesan dakwah adalah pesan yang

18 Agung Setiyawan, "Budaya Lokal Dalam Perspektif Agama: Legitimasi Hukum Adat (“Urf) Dalam Islam,” ESENSIA: Jurnal Ilmu-Ilmu Ushuluddin 13, no. 2 (22 Juli 2012): 210, https://doi.org/10.14421/esensia.v13i2.738.

19 Anshari, Wawasan Islam: Pokok-Pokok Pikiran tentang Paradigma dan Sistem Islam, 44 .

${ }^{20}$ Mualimin dkk., "Cultural Da'wah of Antar Pinang Pulang Memulangkan Tradition in Sambas Malay Society, West Kalimantan," Ilmu Dakwah: Academic 
berupa ajaran Islam atau segala sesuatu yang harus disampaikan kepada objek dakwah. Isi pesan tersebut yaitu keseluruhan ajaran Islam yang ada dalam Al-Qur'an dan hadis. Sukayat menambahkan bahwa saat ini perlu adanya reorientasi terhadap esensi pesan dakwah. Pesan dakwah mestinya tidak hanya terkait dengan persoalan ibadah saja, tetapi juga harus menyentuh aspek problematika kemanusiaan. ${ }^{21}$ Oleh karena itu dalam pandangan Aziz, pesan dakwah terbagi menjadi tiga dimensi. ${ }^{22}$ Menurut Anshari pembagian dimensi pesan dakwah yaitu pesan akidah, syariat, dan akhlak.

Pesan dakwah dalam tradisi saprahan saling terkait antara satu sama lain. Secara utuh pesan dakwah dalam tradisi saprahan adalah manusia harus beriman meyakini adanya Allah. Konsekuensi dari keimanan yaitu dengan bersumpah bahwa hanya untuk bertauhid kepada Allah. Keyakinan ini akan mengantarkan manusia mendapatkan predikat taqwa. Orang yang bertaqwa cirinya adalah konsistensi menjalankan perintah-perintah Allah dan menjauhi larangannya. Diantara bentuk realisasi ketaqwaan adalah dengan mendirikan shalat. Ketaatan mendirikan shalat ini jika dilakukan dengan benar dan konsisten akan mampu menghindarkan umat Islam dari melakukan perbuatan yang tercela. Realisasi ketaqwaan ini kemudian akan melahirkan akhlak mulia yaitu senantiasa menjaga persatuan, kesetaraan, dan senang membantu sesama.

Pesan dakwah dalam tradisi makan besaprah secara spesifik dapat dipetakan sebagai berikut :

a. Pesan Akidah

Akidah berasal kata al-'aqdu yang artinya ikatan. Menurut Anshari akidah dapat diartikan sebagai ikatan, kepercayaan, keyakinan, dan keimanan. Merujuk pada pendapat tersebut, ruang lingkup pesan akidah adalah pada tataran keimanan dan ketauhidan Allah SWT. ${ }^{23}$

\footnotetext{
Journal for Homiletic Studies 12, no. 2 (30 Desember 2018): 207, https://doi.org/10.15575/idajhs.v12i2.1909.

21 Sukayat, Ilmu Dakwah Perspektif Filsafat Mabadi 'Asyarah, 25-26.

${ }^{22}$ Aziz, Ilmu Dakwah, 114.

${ }^{23}$ Anshari, Wawasan Islam: Pokok-Pokok Pikiran tentang Paradigma dan Sistem Islam,
} 44. 
Dalam tradisi saprhan pesan akidah direpresentasikan dengan ketentuan jumlah sendok dalam satu saprah adalah dua buah. Angka dua ini pada dasarnya adalah simbolisasi syahadat. Makna dari simbolisasi ini adalah pesan bahwa manusia harus mengakui dan bersumpah bahwa hanya Allahlah satu-satunya Tuhan yang pantas disembah, dan mengakui bahwa Nabi Muhammad adalah utusan Allah SWT. Jumlah sendok yang dua buah ini juga merupakan simbolisasi AlQur'an dan Hadis sebagai sumber utama ajaran Islam dan referensi utama tentang keesaan Allah Swt. Implikasi dari sumpah yang direfleksikan dalam syahadat adalah lahirnya keimanan yang terangkum dalam rukun iman. Rukun iman ini direpresentasikan melalui ketentuan jumlah orang dan jenis lauk pauk dalam satu saprah yaitu enam atau lima. Ketentuan ini menyesuaikan dengan keadaan sebagaimana yang telah dijelaskan sebelumnya dalam poin simbolisasi tradisi makan besaprah. Angka enam ini pada dasarnya adalah jumlah rukun iman.

b. Pesan Syariat

Dimensi syariat adalah pesan dakwah yang terkait dengan aturan dan ketentuan hukum dalam pengamalan ajaran Islam seperti ibadah dan muamalah. Menurut Amin, syariat adalah sistem aturan yang dibuat oleh Allah untuk manusia baik secara terperincin maupun pokok-pokoknya saja. ${ }^{24}$ Sedangkan menurut Anshari, syariat Islam adalah suatu sistem norma Ilahi yang mengatur hubungan timbal balik secara vertikal antara manusia dengan Tuhan dan hubungan timbal balik antara manusia dengan sesama ciptaan Tuhan.$^{25}$

Pesan Syariat dalam tradisi makan besaprah direpresentasikan dengan ketentuan jumlah orang dan jenis lauk yang jumlahnya lima. Angka lima ini adalah simbolisasi kewajiban shalat bagi setiap umat Islam yang telah baligh. Selain itu angka lima juga merupakan simbolisasi dari rukun

24 Wildan Rijal Amin, "Kupatan: Tradisi untuk Melestarikan Ajarana Bersedekah, Memperkuat Tali Silaturahmi, dan Memuliakan tamu," Al-A'raf: Jurnal Pemikiran Islam dan Filsafat 14, no. 2 (20 Desember 2017): 12, https://doi.org/10.22515/ajpif.v14i2.893.

${ }^{25}$ Anshari, Wawasan Islam: Pokok-Pokok Pikiran tentang Paradigma dan Sistem Islam, 45. 
Islam. Pesan yang terkandung melalui angka lima ini adalah pengamalan rukun Islam merupakan konsekuensi dari keimanan kepada Allah SWT. Oleh karena itu pengamalan rukun Islam ini harus berdasarkan tuntunan yang terdapat dalam Al-Qur'an maupun yang dijelaskan dalam Hadis.

c. Pesan Akhlak

Pesan akhlak sangat dominan ditemukan dalam tradisi makan besaprah. Hampir keseluruhan pesan dalam makan besaprah adalah terkait dengan kemuliaan akhlak. Realitas ini menunjukkan bahwa kemuliaan akhlak menjadi sangat penting bagi Melayu Sambas.

Akhlak merupakan refleksi dari kemuliaan hati bagi orang Melayu. Lim Kim Hui menyebutkan bahwa hati bagi orang Melayu tidak hanya berdimensi emosi tetapi juga berdimensi spiritual. Dalam konteks ini Hui membagi konsep hati secara peremiologis menjadi dua kategori. Pertama, hati sebagai inti, seperti hati kecil, hati sanubari, dan berhati batu. Kedua, hati sebagai pembatas, seperti iri hati, baik hati, dan isi hati. ${ }^{26}$ Pendapat tersebut pada dasarnya menunjukkan bahwa kemuliaan akhlak seseorang adalah buah dari keimanannya. Oleh karena itu pesan akhlak yang mendominasi dalam makan besaprah bukan berarti mengabaikan pesan akidah, secara tidak langsung justru menegaskan bahwa akidah sangat penting sehingga membuahkan akhlak yang mulia.

Pesan akhlak dalam tradisi makan besaprah dapat diklasifikasi sebagai berikut :

1) Silaturahmi dan Ta'awun (tolong menolong)

Secara tekstual tradisi makan besaprah memperlihatkan adanya kebersamaan masyarakat dalam mempersiapkan hidangan. Hal ini diwujudkankan dengan gotong royong ketika membuat tempat acara dan memasak. Setiap individu yang terlibat dalam tradisi saprahan ini tidak berorientasi pada profit, tetapi pada rasa kekeluargaan dan solidaritas sosial.

${ }^{26}$ Kim Hui Lim, "How Malay Proverbs Encode and Evaluate Emotion? A Paremiological Analysis," SARI: International Journal of The Malay World and Civilization 28, no. 1 (2010): 75. 
Kuatnya hubungan kekeluargaan yang ditampilkan dalam tradisi makan besaprah merupakan representasi sistem sosial Melayu Sambas. Masyarakat Melayu Sambas menurut Kaspullah pada umumnya masih dominan pada keluarga luas (extended family). Hubungan kekerabatan tidak hanya pada keluarga inti, tetapi juga terdiri dari saudara kandung, sepupu, saudara dari pihak suami-istri. Pendapat Kaspullah ini menunjukkan bahwa keluarga dalam Melayu Sambas tidak hanya yang memiliki hubungan darah langsung, tetapi dapat juga melalui sebab lain seperti pernikahan dan adopsi. Realitas tersebut menunjukkan bahwa hubungan kekerabatan menjadi sangat penting dalam kehidupan Melayu Sambas. ${ }^{27}$

Hubungan kekerabatan sangat penting dalam membangun sebuah tatanan kehidupan sosial yang kondusif. Implikasi dari hubungan kekerabatan dalam kehidupan Melayu Sambas adalah terciptanya budaya tolong menolong. Kondisi ini akan memungkinkan terjadinya percepatan pembangunan dalam masyarakat tersebut. Oleh karena itu, Islam memandang penting hubungan sosial yang kondusif dalam masyarakat. Tindakan dalam Al-Qur'an juga disebutkan dalam AliImran ayat 102-103 bahwa yang dapat membangun hubungan sosial dan persatuan dalam masyarakat dalam Al-Qur'an merupakan indikator ketaqwaan seseorang. Konsep hubungan sosial ini juga dijabarkan pada berbagai bentuk implementasi ajaran Islam terkait tolong menolong, salah satunya adalah zakat dan shadaqah. Ajaran tersebut menurut Rama tidak hanya memiliki dimensi ibadah, namun juga memiliki dimensi sosial ekonomi. ${ }^{28}$

Menurut Venus pentingnya hubungan kekeluargaan yang berimplikasi pada budaya tolong menolong dalam

27 Kaspullah, "Nilai-Nilai Al-Qur'an dan Hadis dalam Tradisi Pernikahan Masyarakat Melayu Sambas" (Yogyakarta, Universitas Islam Negeri Sunan Kalijaga, 2010), 143, http:/ / digilib.uin-suka.ac.id/6982.

28 Rama Wijaya Kesuma Wardhani, “Manajemen Komunikasi Badan Amil Zakat Nasional (BAZNAS) Provinsi Jawa Barat," NALAR: Jurnal Peradaban dan Pemikiran Islam 2, no. 1 (29 Agustus 2018): 12, https://doi.org/10.23971/njppi.v2i1.923. 
kehidupan Melayu tergambar jelas dalam ungkapan Melayu berikut :

Hidup sedesa rasa merasa

Hidup sebangsa bertimbang rasa

Menenggang perasaan orang, menjaga tali saudara

Dicubit paha kanan, sakitnya ke paha kiri ${ }^{29}$

Pesan tentang pentingnya silaturahmi dan ta'awun terdapat dalam tahapan-tahapan pelaksanaan tradisi makan besaprah. Pada setiap tahapan dalam pelaksanaan makan besaprah, keluarga dan tetangga saling tolong-menolong agar tradisi ini terlaksana dengan baik. Bantuan tersebut tidak dibatasi pada bantuan materi seperti uang dan barang, tetapi juga bantuan moril berupa tenaga dan pikiran. Hubungan saling membantu tersebut kemudian membangun ikatan emosional antara sesama anggota masyarakat. Pada gilirannya akan terbangun rasa saling memiliki antara satu sama lain.

2) Memuliakan sesama terutama tamu dan orang tua

Melayu Sambas sangat memuliakan orang tua dalam kehidupan sehari-hari. Memuliakan orang tua bagi Melayu Sambas dipandang sebagai kunci untuk mendapatkan keberkahan hidup. Selain itu masyarakat Melayu percaya bahwa orang yang tidak memuliakan orang tua akan mendapat masalah yang disebut juga dengan istilah tullah. Pesan untuk memuliakan orang tua tergambar pada aturan yang tidak boleh mendahului orang tua baik untuk memulai maupun mengakhiri makan besaprah.

Melayu Sambas juga sangat memuliakan tamu apalagi tamu yang sengaja diundang. Pada tataran ini makan besaprah merupakan perjamuan dalam rangka menghormati dan memuliakan tamu. Bagi Melayu Sambas, memuliakan tamu merupakan akan membuka pintu keberkahan dari Allah SWT. Pesan tentang memuliakan tamu dalam makan besaprah tergambar dari penyajian makanan dalam dengan mengedepankan estetika dan menggunakan peralatan terbaik yang dimiliki.

${ }^{29}$ Antar Venus, Filsafat Komunikasi Orang Melayu (Bandung: Simbiosa Rekatama Media, 2015), 129. 
Memuliakan tamu merupakan bentuk keterbukaan Melayu Sambas terhadap kedatangan orang luar. Menurut Husni Tamrin, orang Melayu selalu terbuka dan memberikan pertolongan terhadap orang yang datang ke kampung halamannya sepanjang dapat menjaga etika dan kesopanan. Sikap ini mengingat terdapat pepatah Melayu "biar rumah sempit, tapi hati lapang". ${ }^{30}$

3) Kesetaraan

Kesetaraan dalam pandangan Mustansyir sangat identik dengan tradisi makan besaprah. ${ }^{31}$ Pesan tersebut direpresentasikan melalui aturan makan yang harus menggunakan tangan. Selain kesetaraan juga direpresentasikan dengan itu tidak ada perbedaan menu masakan didasarkan pada status sosial. Pada tataran ini, tatacara dalam makan besaprah secara tidak langsung menempatkan manusia dalam kesetaraan. Realitas tersebut pada dasarnya merupakan implementasi dari "duduk sama rendah, berdiri sama tinggi".

Pesan kesetaraan dalam makan besaprah merupakan manifestasi dari ajaran Islam tentang egaliter. Dalam pandangan Suhra persamaan antara manusia merupakan suatu keniscayaan dalam Islam. Konsekuensi dari prinsip tersebut manusia memiliki hak dan peluang yang sama dihadapan Allah SWT. ${ }^{32}$ Menurut Barir bahwa konsep kesetaraan dalam Islam terkait erat dengan keseimbangan hak, keadilan dan sikap moderat terhadap perbedaan yang bermuara pada nilai kemanusiaan. ${ }^{33}$

\footnotetext{
${ }^{30}$ Husnu Tamrin, "Enkulturisasi dalam Kebudayaan Melayu," Al-Fikra: Jurnal Ilmiah Keislaman 14, no. 1 (14 September 2017): 121, https://doi.org/10.24014/af.v14i1.3903.

${ }^{31}$ Rizal Mustansyir, Kearifan Lokal Masyarakat Melayu Sambas Dalam Tinjauan Filosofis, ed. oleh Amin Ma'ruf, vol. 1 (Yogyakarta: Fakultas Filsafat UGM, 2015), 179-83, https:// repository.ugm.ac.id/273529/.

32 Sarifa Suhra, "Kesetaraan Gender Dalam Perspektif Al-Qur'an Dan Implikasinya Terhadap Hukum Islam," Al-Ulum 13, no. 2 (1 Desember 2013): 374.

33 Muhammad Barir, "Kesetaraan Dan Kelas Sosial Dalam Perspektif AlQur'an," Jurnal Studi Ilmu-Ilmu Al-Qur'an Dan Hadis 15, no. 1 (13 Januari 2014): 87, https://doi.org/10.14421/qh.2014.1501-04.
} 


\section{E. Simpulan}

Berdasarkan hasil dan analisis yang telah dilakukan, dapat disimpulkan bahwa ajaran Islam disampaikan melalui simbol-simbol budaya yang dikemas secara baik dalam tradisi makan besaprah. Pesan dakwah dalam tradisi makan besaprah disampaikan melalui simbolsimbol budaya. Secara umum pesan dakwah tersebut dapat dibagi pada tiga aspek ajaran Islam. Pertama, pesan akidah terkait ketauhidan dan rukun iman. Kedua, pesan syariat terkait ketaatan melaksanakan ajaran Islam dalam kehidupan sehari-hari. Ketiga, pesan akhlak terkait silaturahmi, tolong menolong, memuliakan manusia, dan kesetaraan derajat antara sesama manusia. 


\section{DAFTAR PUSTAKA}

Achsani, Ferdian, dan Siti Aminah Nur Laila. "Pesan Dakwah Dalam Lirik Lagu Menyambut Lebaran Karya Pendhoza." NALAR: Jurnal Peradaban Dan Pemikiran Islam 3, no. 2 (2019): 122-33. https://doi.org/10.23971/njppi.v3i2.1435.

Amin, Wildan Rijal. "Kupatan: Tradisi untuk Melestarikan Ajarana Bersedekah, Memperkuat Tali Silaturahmi, dan Memuliakan tamu." Al-A'raf: Jurnal Pemikiran Islam dan Filsafat 14, no. 2 (20 Desember 2017): 267. https://doi.org/10.22515/ajpif.v14i2.893.

Anshari, Endang Saifudin. Wawasan Islam: Pokok-Pokok Pikiran tentang Paradigma dan Sistem Islam. Jakarta: Gema Insani, 2004.

Anwar, Herles, dan Mualimin. “Dakwah Melalui Pembinaan Keagamaan Terhadap Masyarakat Muslim Pedalaman Oleh Penyuluh Agama Islam Non PNS Kecamatan Tebas, Sambas." Jurnal Bimbingan Penyuluhan Islam 1, no. 01 (30 Juni 2019): 23-36.

Arpan, S. Saprahan: Adat Budaya Melayu Sambas. Tebas: Arjuna Offset, 2009.

Astori, Asep Kamil, dan Eka Octalia Indah Librianti. "Dakwah Kultural: Relasi Islam Dan Budaya Lokal." Ath Thariq Jurnal Dakwah Dan Komunikasi 3, no. 2 (26 Februari 2020): 179-92. https://doi.org/10.32332/ath_thariq.v3i2.1548.

Aziz, Moh Ali. Ilmu Dakwah. Jakarta: Kencana, 2009.

Barir, Muhammad. "Kesetaraan Dan Kelas Sosial Dalam Perspektif Al-

Qur'an." Jurnal Studi Ilmu-Ilmu Al-Qur'an Dan Hadis 15, no. 1 (13 Januari 2014): 61-92. https://doi.org/10.14421/qh.2014.1501-04.

Basit, Abdul. Filsafat Dakwah. Jakarta: Raja Grafindo Persada, 2013.

Kaspullah. "Nilai-Nilai Al-Qur'an dan Hadis dalam Tradisi Pernikahan Masyarakat Melayu Sambas." Universitas Islam Negeri Sunan Kalijaga, 2010. http://digilib.uin-suka.ac.id/6982.

Lim, Kim Hui. "How Malay Proverbs Encode and Evaluate Emotion? A Paremiological Analysis." SARI: International Journal of The Malay World and Civilization 28, no. 1 (2010): 57-81.

Mondry. Pemahaman Teori dan Praktik Jurnalistik. Bogor: Ghalia Indonesia, 2008.

Mualimin, Ari Yunaldi, Sunandar, dan Alkadri. “Cultural Da'wah of Antar Pinang Pulang Memulangkan Tradition in Sambas Malay Society, West Kalimantan." Ilmu Dakwah: Academic Journal for Homiletic Studies 12, no. 2 (30 Desember 2018): 201-2013. https://doi.org/10.15575/idajhs.v12i2.1909. 
Mulyana, Deddy. Ilmu Komunikasi: Suatu Pengantar. Bandung: Remaja Rosdakarya, 2007.

Mun'in, Fathan. "Eksistensi Tradisi Pembacaan Assalai/Asy'rakal dan Makan Besaprah pada Pesta Pernikahan Masyarakat Melayu Kabupaten Sambas Perspektif Ekonomi Islam." Khatulistiwa: Journal Of Islamic Studies 1, no. 2 (2017): 18.

Munir, Muhamad, dan Wahyu Ilaihi. Manajemen Dakwah. Jakarta: Kencana, 2015.

Musa, Pabali. "Tahapan-Tahapan Sejarah Sambas." Makalah dipresentasikan pada Dies Natalis STAI Sambas tahun 2010, Sambas, 2010.

Mustansyir, Rizal. Kearifan Lokal Masyarakat Melayu Sambas Dalam Tinjauan Filosofis. Disunting oleh Amin Ma'ruf. Vol. 1. Yogyakarta: Fakultas Filsafat UGM, 2015. https://repository.ugm.ac.id/273529/.

Pemerintah Daerah Kabupaten Sambas. "Kondisi Umum Kabupaten Sambas." Diakses 12 April 2020. https://sambas.go.id/profiledaerah/pemerintahan/kondisi-umum.html.

Setiyawan, Agung. "Budaya Lokal Dalam Perspektif Agama: Legitimasi Hukum Adat ('Urf) Dalam Islam.” ESENSIA: Jurnal Ilmu-Ilmu Ushuluddin 13, no. 2 (22 Juli 2012): 203-22. https://doi.org/10.14421/esensia.v13i2.738.

Suhra, Sarifa. "Kesetaraan Gender Dalam Perspektif Al-Qur'an Dan Implikasinya Terhadap Hukum Islam." Al-Ulum 13, no. 2 (1 Desember 2013): 373-94.

Sukayat, Tata. Ilmu Dakwah Perspektif Filsafat Mabadi 'Asyarah. Bandung: Simbiosa Rekatama Media, 2015.

Sukir, Asmuni. Dasar-Dasar Strategi Dakwah. Surabaya: Al-Ikhlas, 1983.

Tamrin, Husnu. “Enkulturisasi dalam Kebudayaan Melayu." Al-Fikra: Jurnal Ilmiah Keislaman 14, no. 1 (14 September 2017): 98-148. https://doi.org/10.24014/af.v14i1.3903.

Venus, Antar. Filsafat Komunikasi Orang Melayu. Bandung: Simbiosa Rekatama Media, 2015.

Wardhani, Rama Wijaya Kesuma. "Manajemen Komunikasi Badan Amil Zakat Nasional (BAZNAS) Provinsi Jawa Barat." NALAR: Jurnal Peradaban dan Pemikiran Islam 2, no. 1 (29 Agustus 2018): 12-21. https://doi.org/10.23971/njppi.v2i1.923.

Widodo, Anton. “Dakwah Di Era Revolusi Industri 4.0." Khabar 1, no. 1 (31 Desember 2019): 49-65. https://doi.org/10.37092/khabar.v1i1.120. 
Yantos, Yantos. "Analisis Pesan-Pesan Dakwah Dalam Syair Lagu Opick." Jurnal Dakwah Risalah 24, no. 2 (1 November 2013): 16-27. https://doi.org/10.24014/jdr.v24i2.20. 